\title{
La responsabilidad extracontractual en Colombia de la administración por vías de hecho
}

The non-contractual liability in Colombia of de facto administration

\author{
A responsabilidade extracontratual na Colômbia da administração \\ de facto
}

\section{Diana Maryury Angulo Marquinez ${ }^{1}$}

Recibido: 13 de noviembre de 2019

Aprobado: 12 de diciembre de 2019

Publicado: 13 de enero de 2020

Cómo citar este artículo:

Diana Maryury Angulo Marquinez. La responsabilidad extracontractual en Colombia de la administración por vías de hecho. DIXI 31. Enero de 2020, 1-37. DOI: https://doi.org/10.16925/2357-5891.2020.01.07

Artículo de investigación. https://doi.org/10.16925/2357-5891.2020.01.07

1 Administradora de Empresas de la Universidad Minuto de Dios sede Cali. Diplomado en Auxiliar Contable, Universidad Libre sede de Cali. Diplomado en Asistente Administrativa, Universidad Libre. Diplomado en Gestión de Negocios Internacionales Universidad Minuto de Dios sede Cali.

Correo electrónico: nadia.178924@hotmail.com. 


\section{Resumen}

Tema y alcance: el presente artículo establece como objeto de investigación la responsabilidad extracontractual imputable a la Administración como consecuencia del ejercicio de funciones de policía judicial.

Características: la investigación propuesta cobra importancia por tratarse del análisis de circunstancias fácticas de común ocurrencia en el caso colombiano (i) por la alta conflictividad que presenta en Colombia la concentración de funciones de policía judicial en el Cuerpo Técnico de Investigación (CTI) de la Fiscalía General de la Nación, el alto número de funcionarios y empleados vinculados a este órgano esencial en la estructura del órgano judicial encargado de la investigación de los hechos punibles; y (ii) por la incursión significativa del personal vinculado a conductas contrarias al orden jurídico en el ejercicio de las funciones asignadas.

Hallazgos: el fundamento legal de la teoría de la responsabilidad en el campo civil son las obligaciones, y son fuente de obligaciones los actos y los hechos jurídicos. Es de los hechos jurídicos ilícitos en los que la responsabilidad jurídica encuentra su sustento jurídico por cuanto obliga a quien ha ocasionado un perjuicio a reparar el daño cometido.

Conclusiones: el tránsito del Estado Absoluto al Estado de Derecho y posteriormente al Estado Social de Derecho trajo, entre otras consecuencias, la transformación del Estado irresponsable al Estado patrimonialmente responsable por los daños que sus agentes causan.

Palabras clave: concentración de funciones, Estado Social de Derecho, orden jurídico responsabilidad extracontractual, vías de hecho.

\section{Abstract}

Subject and scope: The objective of this article is to establish the extra-contractual liability attributable to the Administration as a consequence of judicial police functions.

Characteristics: The proposed investigation is important because it is an analysis of factual circumstances of common occurrence in the Colombian case (i) due to the high level of conflict in Colombia by the concentration of judicial police functions in the Cuerpo Técnico de Investigación (cti) of the Fiscalía General de la Nación, the high number of officials and employees linked to this essential body in the structure of the judicial body in charge of investigating punishable acts; and (ii) due to the significant incursion of personnel linked to conduct, contrary to the legal order, in the exercising of their assigned functions.

Findings: Obligations form the legal basis for the theory of liability in the civil field; and legal acts and facts are the source of obligations. From the illegal act, legal responsibility finds its legal basis in that it forces the person who has caused a loss to repair the damage committed.

Conclusions: The transition from the Absolute State to the State of Law and later to the Social State of Law brought, among other consequences, the transformation of the unaccountable State to the State that is financially responsible for the damages caused by its agents.

Keywords: concentration of functions, social rule of law, legal order, tort liability, de facto routes.

\section{Resumo}

Objecto e âmbito: este artigo estabelece como objecto de investigação a responsabilidade extracontratual imputável à Administração em consequência do exercício das funções de polícia judiciária.

Características: a investigação proposta torna-se importante por se tratar de uma análise de circunstâncias factuais de ocorrência comum no caso colombiano (i) devido ao alto nível de conflito na Colômbia devido à concentração de funções de polícia judiciária no Órgão Técnico de Investigação (CTI) do Procuradoria-Geral 
da República, o elevado número de funcionários e empregados vinculados a este órgão essencial na estrutura do órgão judiciário encarregado da investigação de atos puníveis; e (ii) pela significativa entrada de pessoal ligado a condutas contrárias à ordem legal no exercício das funções atribuídas.

Conclusões: a base jurídica da teoria da responsabilidade civil são as obrigações, e os atos e fatos jurídicos são a fonte das obrigações. É um dos atos jurídicos ilegais em que a responsabilidade jurídica encontra a sua base jurídica no sentido de obrigar o causador do dano a reparar o dano cometido.

Conclusões: a passagem do Estado Absoluto para o Estado de Direito e posteriormente para o Estado Social de Direito trouxe, entre outras consequências, a transformação do Estado irresponsável em Estado financeiramente responsável pelos danos causados por seus agentes.

Palavras-chave: concentração de funções, Estado Social de Direito, ordem jurídica responsabilidade extracontratual, rotas de fato.

\section{INTRODUCCIÓN}

La responsabilidad extracontractual de la Administración es una institución típica del derecho administrativo que conserva la naturaleza originaria de configuración pretoriana propia del origen de este subsistema jurídico en el derecho francés, en cuanto su mayor dinámica deriva de los pronunciamientos jurisprudenciales originados en la solución de casos concretos.

La característica anotada ha permitido que los límites de la responsabilidad extracontractual de la Administración estén dados por los regímenes de responsabilidad aceptados por la Jurisprudencia, clasificándose ellos tradicionalmente entre objetivos y subjetivos. No obstante lo anterior, la responsabilidad extracontractual de la Administración también deriva de disposiciones jurídicas expresas tanto constitucionales como legales, que en el caso colombiano y en vigencia de la Constitución de 1886 se fundamentaba en el artículo 16. Pero en tiempos de la Constitución de 1991, se escribió una norma expresa, contenida en su artículo 90, que introdujo el concepto de daño antijurídico como fundamento de la imputación de responsabilidad al Estado, la cual ha tenido desarrollos legales en disposiciones posteriores que en casos generales y particulares han regulado la existencia de responsabilidad patrimonial y, como consecuencia de ello, la indemnización a forfait.

Las vías de hecho, tradicionalmente en el derecho administrativo, se han considerado como una forma de expresión jurídica de la Administración, ligada o relacionada con la comisión de delitos o de procedimientos contra legem dados en el desempeño de funciones administrativas; y tiene efectos jurídicos en la medida en que causa daño imputable a la Administración. 
Las funciones de policía judicial se definen como aquellas ejercidas por el conjunto de autoridades que colaboran con el sistema judicial en la investigación de los delitos y captura de los delincuentes. En el caso colombiano, aunque estas funciones son ejercidas por varias autoridades, por mandato del artículo constitucional se prestan bajo la coordinación de la Fiscalía General de la Nación, ente de la rama judicial del poder público que en su estructura interna asigna la coordinación y ejecución de funciones de policía judicial al cuerpo técnico de investigación.

\section{ANTECEDENTES}

El tránsito del Estado Absoluto al Estado de Derecho y posteriormente al Estado Social de Derecho, trajo, entre otras consecuencias, la transformación del Estado irresponsable al Estado patrimonialmente responsable por los daños que sus agentes causan. Está mutación ha permitido desarrollar, en el cuerpo del derecho administrativo de origen europeo continental, un dinámico componente denominado derecho de responsabilidad extracontractual del Estado, el cual se caracteriza por su configuración mayoritariamente jurisprudencial, la cual implica que su mayor desarrollo está ligado a los pronunciamientos de los jueces y tribunales contencioso administrativos.

Esta característica esencial ha traído aparejado que su columna vertebral esté compuesta por los denominados regímenes de responsabilidad, que se distinguen como construcciones conceptuales que alinderan las circunstancias fácticas y jurídicas en las cuales el Estado resulta responsable por la acción u omisión de sus agentes. Así, se vuelve de causa obligatoria establecer, para cada escenario de imputación de responsabilidad, cuál régimen de responsabilidad del Estado es aplicable como presupuesto de la declaratoria de responsabilidad y como condena consecuencial a la indemnización de los perjuicios derivados del daño.

En el derecho administrativo colombiano, a partir de la vigencia de la Constitución de 1991, se parte del concepto de daño antijurídico contenido en el artículo 90 de la norma superior, al cual se adscriben los regímenes subjetivos de falla del servicio probada y presunta, así como los objetivos de daño especial y riesgo excepcional.

A la Administración, como sujeto de derecho, se le reconocen ciertas formas de expresión jurídica, y entre ellas se distinguen las vías de hecho, que se pueden definir como el proceder torcido o abiertamente ilegal de la administración en el ejercicio de sus funciones, la cual ha contado históricamente con el reconocimiento de efectos jurídicos a partir de la causación de un daño resarcible. En este orden y concatenando con lo dicho en párrafos anteriores, si las vías de hecho causan daño resarcible, habrá lugar a la imputación de responsabilidad de la Administración en la medida en 
que la situación fáctica y jurídica encuadre dentro de cualquiera de los regímenes de responsabilidad aceptados por la jurisprudencia. Por tanto, es de capital importancia determinar el régimen de responsabilidad aplicable a la responsabilidad de la Administración derivada de la vía de hecho.

Las funciones de policía judicial ejercidas por los funcionarios y empleados vinculados al Cuerpo Técnico de Investigación (CTI) de la Fiscalía General de la Nación consisten, entre otras, en acciones materiales tales como allanamientos de inmuebles y vehículos, retención y detención de personas, práctica de pruebas técnico-científicas, aprehensión de bienes muebles y custodia de pruebas. Todo esto, por principio de legalidad, está absolutamente reglado, por tanto el lindero entre lo legal y lo ilegal se hace más delgado ante la concentración de funciones, el gran número de empleados y funcionarios con competencias de policía judicial, la repetición de las actividades, la alta complejidad y el valor patrimonial envuelto en las relaciones jurídicas que se crean.

Las funciones de policía judicial ejercidas por el CTI concitan alto riesgo de incursión en vías de hecho por las razones dadas en el párrafo anterior, lo cual trae como consecuencia una tendencia creciente de los destinatarios de la Administración de Justicia en demandar al Estado por causas relacionadas con la actuación del CTI. Esto plantea un problema jurídico de interés para el derecho administrativo en dos dimensiones: una es la de los justiciables para establecer el régimen de responsabilidad del Estado a invocar como sustento de las pretensiones, y la otra, la de la Administración en tener certeza del régimen de responsabilidad aplicable para oponer los argumentos en su defensa.

Aunque el derecho de responsabilidad en Colombia tiene un desarrollo jurisprudencial y doctrinal amplio, los estudios y desarrollos sobre el problema planteado no son copiosos ni completos, por lo cual focalizar esta investigación en el objeto planteado en nuestro criterio es de interés académico relevante.

\section{CARACTERÍSTICAS GENERALES}

El derecho de acceso a la Administración de Justicia en el ordenamiento jurídico colombiano tiene la naturaleza de fundamental, y a su vez la sociedad colombiana se distingue por un alto nivel de conflictividad. Consecuencia de ello es la creciente demanda de justicia, circunstancia que desborda la capacidad institucional de ofrecerla de manera pronta y eficaz, con lo que se califica a la justicia que se ofrece en Colombia como morosa y con una carga negativa expresada en una permanente congestión. Este panorama visto desde la especificidad de la justicia penal cobra 
mayor dramatismo, en cuanto la omisión en la investigación y sanción de los delitos tiene un mayor impacto en la sociedad. Como respuesta a este fenómeno, el Estado ha desarrollado en los últimos veinte años una política de fortalecimiento de la justicia penal, expresada en los siguientes ejes: cambio del sistema inquisitivo al sistema acusatorio, ampliación de la planta de empleos de la Fiscalía General de la Nación, ampliación del número de jueces y magistrados de competencia penal, inversión en infraestructura y tecnología para apoyar las investigaciones, y construcción y mejoramiento de cárceles.

En desarrollo de la política y la ejecución de las acciones de investigación y sanción de los delitos, ha incrementado el porcentaje de condenas en contra de la Nación por daños derivados de privaciones injustas de la libertad, pero también crece el número de demandas por daños causados por vías de hecho generadas en el ejercicio de funciones de policía judicial ejecutadas por agentes del CTI adscritos a la Fiscalía General de la Nación.

Si bien este último fenómeno señalado podría atemperarse en la tradicional doctrina de las vías de hecho en que incurren los miembros de los cuerpos armados de seguridad del Estado, la solución no es suficiente por varias razones, a saber: el CTI es el órgano de la Administración que más participa en actividades de policía judicial, tiene a su cargo el manejo de armas aunque no es un cuerpo armado, despliega actividades de restricción de derechos fundamentales de manera permanente y es sustento del sistema penal acusatorio. Esta nutrida y particular caracterización justifica la necesidad de ubicar este daño dentro del régimen jurisprudencial de la responsabilidad de la Administración, analizar en qué teoría general se encuadra y qué circunstancias lo particularizan conceptualmente. En este contexto, se justifica el trabajo de investigación propuesto.

Adicionalmente, el objeto de investigación tiene interés académico para el desarrollo del derecho administrativo, para la formación profesional de los autores, para la cualificación investigativa de la universidad y como factor de calidad de la Maestría en Derecho Administrativo.

\section{MARCOS DE REFERENCIA}

El concepto de vías de hecho en derecho administrativo no ha sido objeto de copiosos estudios. En la doctrina administrativista tradicional, en los denominados clásicos podemos encontrar referencias al tema, entre las cuales se destacan las siguientes: 
Jean Rivero:

La administración en el ejercicio de sus prerrogativas puede provocar un grave atentado a las libertades y a las propiedades; los particulares disponen, en este caso, de recursos de anulación y de indemnización ante el Juez administrativo. Pero más allá de un cierto grado en la irregularidad, la administración es considerada como apartada del cumplimiento de la función. Su actuación no aparece más como el ejercicio irregular de una de sus atribuciones, sino como un puro hecho material, desprovisto de toda justificación jurídica. Ella no puede entonces prevalerse del principio de separación y de la competencia administrativa: el acto ha perdido todo carácter administrativo, está desnaturalizado; es el Juez judicial a quien corresponde, por consiguiente, asegurar la protección al particular?

Eduardo García De Enterría:

El concepto de vía de hecho es una construcción del Derecho administrativo francés, en el que tradicionalmente se distinguen dos modalidades, según que la Administración haya usado un poder del que legalmente carece (manque de droit) o lo haya hecho sin observar los procedimientos establecidos por la norma que le ha atribuido ese poder (manque de procedure).

Esta construcción clásica opera inicialmente en el ámbito de la propiedad y de los derechos matrimoniales, de los que la administración no puede apoderarse legítimamente sino a través del instituto de la expropiación forzosa. En este ámbito patrimonial, tiene además su expresión más acabada, que sirve de modelo para todos los supuestos posibles (especialmente en el campo de las libertades públicas), a los que posteriormente se ha generalizado hasta constituir una sanción general para todos los casos de actuación material irregular de la Administración.²

1 Jean Rivero. DERECho administrativo. Caracas: Editorial Universidad Central de Venezuela. (2005). Pág. 172.

2 Eduardo García de Enterría y Tomás Ramón Fernández. CURSO DERECHO ADMINISTRATIVO. томо 1. Madrid: Editorial Civitas (1977). Pág. 738. 
Enrique Sayagues Laso:

Los hechos de ejecución deben ajustarse a lo dispuesto en el acto cuyo cumplimiento procuran, así como a las formalidades legales aplicables. La violación de este principio configura una irregularidad y si ocasiona perjuicios, compromete la responsabilidad de la administración. Igualmente surge responsabilidad si los hechos de ejecución se ajustaron al acto pero este era ilegal, aun mismo si hubieren vencido los plazos para impugnarlo en vía administrativa o jurisdiccional. En ambos casos dicha responsabilidad se discute ante el Poder Judicial. La doctrina francesa considera estos casos como una vía de hecho de la administración, que origina responsabilidad ante los jueces comunes. ${ }^{3}$

En la doctrina nacional, encontramos, entre otros, el pronunciamiento del profesor Jaime Orlando Santofimio Gamboa:

En Colombia con la vigencia original de los artículos 83 y 86 del Decreto O1 de 1984 se venían sosteniendo dos hipótesis concretas de vía de hecho. Una, cuando la administración obraba en ejercicio de un pretendido derecho que no tenía, caso en el cual debía entenderse que el derecho ejercitado no existía, faltaba absolutamente, porque, delo contrario, si había así fuere un principio de poder, se estaría tipificando un claro exceso de poder. Otra, cuando en el ejercicio de un derecho que realmente se tenía, se actuaba con ausencia total de procedimiento legal. En estos eventos se estaba ante una ausencia total de procedimiento y no ante una irregularidad procedimental. El Decreto 2304 de 1989 desmontó el concepto de vía de hecho del derecho positivo, dejando que las situaciones fácticas que la constituían configuraran otras expresiones de la Administración más coherentes con su naturaleza, como por ejemplo las operaciones administrativas si la vía de hecho se configura en las actuaciones tendientes a darle eficacia al acto administrativo, o alguna de las causales de nulidad del acto, si el grosero desconocimiento del ordenamiento y la violación a los derechos fundamentales se produce durante la etapa de formación del acto administrativo. ${ }^{4}$

3 Enrique Sayague Laso. tRatado DE DERECHo Administrativo. Tomo 1. Montevideo: Editorial Clásicos Jurídicos Uruguayos. (2004). Pág. 494.

4 Jaime Alberto Santofimio Gamboa. TRATAdo DE DERECHo ADMINISTRATIVo. TOMo 2. Bogotá: Editorial Universidad Externado de Colombia. (2003). 


\section{TEORIZACIÓN}

En general, se puede decir que la responsabilidad es la obligación que surge para una persona de indemnizar a otra cuando le ha causado daño injustificadamente. Este aserto, llevado al sujeto de derecho Administración, nos indica que cuando esta infiere daño injustificado a otro sujeto de derecho, tiene la obligación de repararlo 5 .

La imputación de responsabilidad a la Administración por producir daño resarcible es una de las características originadas en el Estado de Derecho y profundizadas en los Estados Constitucionales Sociales de Derecho, en la medida en que el sometimiento de los gobernantes a la Ley y el reconocimiento de derechos públicos subjetivos implicaron el paso del Estado irresponsable al Estado responsable 6 .

Aunque es evidente que se produjeron antecedentes europeos del derecho de responsabilidad, todos los tratadistas coinciden en establecer el Fallo Blanco como el hito que desencadenó en Francia, y posteriormente en toda la Europa continental, el componente del derecho administrativo denominado derecho de responsabilidad?.

5 Por la facilidad con que puede apreciarse, el daño es objeto del conocimiento común. Pero además de ser un fenómeno físico, puede integrar un fenómeno jurídico, es decir, susceptible de ser jurídicamente calificado $y$, desde este punto de vista, entra en los dominios del estudio de los juristas. Adriano De Cupis. EL DAÑo. Barcelona: Editorial Bosch. (1975). Pág. 81.

6 "La respuesta fue al comienzo negativa: la irresponsabilidad de la potestad pública aparecía, en la primera mitad del siglo XIX, como un corolario de la soberanía. Esta solución, muy rigurosa para los particulares, era aceptable en la práctica, en la medida en que el Estado liberal, teniendo estrictamente limitadas sus actividades, tenía relativamente pocas ocasiones de causar daños. El rigor del principio se encontraba, por otra parte, atenuado: la Ley 28 pluvioso del año VIII permitía la reparación de daños causados por las obras públicas; la irresponsabilidad no se extendía ni a los daños imputables a la gestión del dominio privado, ni a aquellos causados por las colectividades locales no soberanas". Ver: Jean Rivero, supra, nota 2, pág. 292.

7 Una niña fue atropellada y herida por una vagoneta de la empresa tabacalera. El conflicto había sido suscitado ante los tribunales ordinarios, por demanda del padre de la niña, en acción por daños y perjuicios contra el Estado como civilmente responsable de las culpas cometidas por los obreros de la empresa manufacturera. El Tribunal de Conflictos debía así resolver el asunto a determinar, retomando los términos de las conclusiones del comisario de gobierno David, "cuál de las dos autoridades jurisdiccionales, administrativa y ordinaria, es la que tiene competencia general para conocer de las acciones por daños y perjuicios en contra del Estado". El fallo dictado en esa oportunidad habría de tener una fortuna singular y durante mucho tiempo se le consideró como el fallo fundamental, la "piedra angular", de todo el derecho administrativo. Hoy, algunos autores sostienen que ese fallo está caducado, aún más, que nunca tuvo la importancia que se le ha acordado. Marceau Long. LOS GRANDES FALLOS DE LA JURISPRUDENCIA ADMINISTRATIVA fRANCESA. Bogotá: Ediciones Librería del Profesional. (2000). Págs. 1-2. 
Entre las características que se le reconocen al derecho de responsabilidad está la de considerarse un derecho pretoriano, por cuanto sus mayores desarrollos no son legislados, sino producidos por la Jurisprudencia 8 .

El derecho de responsabilidad francés tuvo gran influencia en el derecho español, y consecuencia de ello es su reflejo en el derecho administrativo colombiano, en el que suelen destacarse tres etapas del derecho de responsabilidad. Una es atribuida a la producción de la Corte Suprema de Justicia, otra es de coexistencia de producción simultánea de la Corte Suprema de Justicia y el Consejo de Estado, y una tercera y última está dada por la consolidación de la Jurisdicción de lo Contencioso Administrativo y la mayor producción jurisprudencial de su órgano de cierre. ${ }^{9}$

Aunque en distintos momentos de la historia del desarrollo del derecho de responsabilidad se ha legislado con objeto del reconocimiento de indemnizaciones a forfait, ello no alcanza a opacar la profundidad que se ha alcanzado en Colombia en relación con el derecho de responsabilidad de construcción judicial. ${ }^{10}$

El concepto de vías de hecho ha sido reconocido en el derecho colombiano como expresión jurídica de la Administración, cuando a partir de su configuración se causa daño y se compromete la responsabilidad extracontractual del Estado. Sin embargo, esta institución no ha sido de aceptación general y tampoco unívoca en relación con los escenarios donde es justificante para imputar responsabilidad a las autoridades.

No obstante lo anterior, las vías de hecho como expresión jurídica de la Administración en el presente trabajo se circunscribe a la producida en las operaciones administrativas desplegadas por el CTI de la Fiscalía General de la Nación, órgano judicial que desarrolla funciones de policía judicial.11

Colombia es un país complejo desde la dimensión de su alta conflictividad. Es de vieja data que su administración de justicia permanece congestionada, lo cual

8 Es lo que ha ocurrido con la teoría de la responsabilidad del Estado, de corte esencialmente pretoriano, cuyos fundamentos, principios y proyecciones, hasta épocas muy recientes, fueron fruto de la capacidad creadora de la jurisdicción contencioso administrativa, apoyada -claro está- en principios y preceptos constitucionales, en deducciones de la jurisprudencia extranjera y en logros de la doctrina. Ver: Alier Hernández. RESPONSABILIDAD EXTRACONTRACTUAL DEL ESTADO. Bogotá: Ediciones Nueva Jurídica. (2007). Pág. 1.

9 La historia de la evolución de la jurisprudencia está marcada por la dualidad de jurisdicciones encargadas de proferir fallos sobre el tema en estudio, por lo que debe hacerse la siguiente presentación: 1) La responsabilidad declarada por la Corte Suprema de Justicia. 2) La responsabilidad declarada por el Consejo de Estado. Ver: Juan Carlos Henao. La responsabilidad patrimonial del Estado en Colombia. Pág. 108. Disponible en http://biblio.juridicas.unam.mx/libros/3/1392/12.pdf

10 Ver, entre otras, la Ley 975.

11 Ver Decreto Nacional 16 de 2014. 
contribuye a la omisión del Estado en ofrecer una pronta y cumplida justicia. Claro está que la conflictividad no solo se expresa en la alta demanda del servicio público de administración de justicia, sino también en la incursión de la comunidad en prácticas de solución de conflictos fundadas en la autotutela ilícita de los derechos, en las vías de hecho o en el ejercicio de la violencia.

Otra variable del problema enunciado en el párrafo anterior es el alto número de litigios en los que la Administración es el sujeto demandado, que contados por el valor de las pretensiones llegan a los 197,1 billones de pesos en términos de la Agencia Nacional de Defensa del Estado con corte a 31 de diciembre de 2013 y a 414 billones pesos en cuentas de la Contraloría General de la Nación, de cuya cifra las demandas contra la Fiscalía General de la Nación alcanzan el $10 \%$. $^{12}$ Este panorama supone inicialmente que la Administración como sujeto demandado genera varios factores negativos de desgaste para el Estado, a saber: funcionarios y empleados en gran número dedicados de manera permanente a la atención de procesos judiciales, y un rubro muy significativo del presupuesto nacional dedicado a la financiación del pago de las sentencias judiciales condenatorias en contra de la Administración.

Históricamente, se ha considerado que la Administración no se defiende o se defiende mal en sede judicial, lo cual agrava su condición de sujeto demandado, en

12 De acuerdo con información suministrada por las entidades a la Agencia Nacional de Defensa Jurídica del Estado (ANDJE), para diciembre de 2013 se reportaban 293526 procesos judiciales activos en contra de las entidades públicas del orden nacional por un valor de \$191,6 billones. El Instituto de Seguros Sociales, en liquidación, y Colpensiones son las entidades más demandadas con 118215 procesos, seguidas por entidades del Sector Defensa como la Caja de Sueldos de Retiro de la Policía Nacional con 20970 procesos, el Ministerio de Defensa Nacional con 18031 procesos, la Policía Nacional con 14715 procesos y la Caja de Retiro de las Fuerzas Militares con 13492 procesos. Igualmente, existe una alta concentración de las pretensiones económicas de los litigios en sectores como Hacienda (22\%), Comercio, Industria y Turismo (15\%) y Fiscalía (10\%). La Superintendencia Financiera de Colombia enfrenta pretensiones alrededor de $\$ 54,2$ billones, seguida por el Ministerio de Hacienda y Crédito Público con $\$ 45,1$ billones, la Superintendencia de Sociedades demandada por $\$ 43,9$ billones y la Fiscalía General de la Nación con $\$ 37,1$ billones. Esta información se obtiene del Sistema Único de Gestión e Información Litigiosa del Estado, sistema administrado por la Agencia Nacional de Defensa Jurídica del Estado, cuyo uso es obligatorio para todas las entidades públicas del orden nacional. Sin embargo, hace unos días la Contraloría General de la República informó a la ciudadanía que las pretensiones de pleitos contra la Nación ascendían a \$412 billones de pesos, cifra totalmente diferente a la que reporta la Agencia; por ello, se sentará en los próximos días con el ente de control y las diferentes entidades para determinar por qué se está reportando información diferenciada e inconsistente frente a los organismos encargados de vigilar la gestión de la actividad litigiosa del Estado. Información tomada de la página web de la Agencia Nacional de Defensa Jurídica del Estadohttp://www.defensajuridica.gov.co/saladeprensa/noticias/ Paginas/290514.aspx 
cuanto muchas de las condenas en su contra derivan de la omisión total de defensa o precariedad en esta.

Al centrar su objeto en establecer el régimen de responsabilidad aplicable a la imputación de daño a la Administración derivada de las vías de hecho en que incurren los agentes del CTI de la Fiscalía General de la Nación en el ejercicio de funciones de policía judicial, la presente investigación busca que se conozcan las condiciones de admisión de la responsabilidad, pero también las de exoneración para la autoridad pública, en la idea de que los aportes académicos no solamente tienen utilidad conceptual, sino también práctica para solucionar problemas concretos de la sociedad.

\section{FUNDAMENTOS JURÍDICOS DE LA RESPONSABILIDAD EXTRACONTRACTUAL DEL ESTADO}

\section{Noción de responsabilidad}

La palabra responsabilidad, producto de la evolución del latín responsāre, tiene sus antecedentes en el derecho romano y su significado es seguridad, restitución o indemnización; en francés, responsabilité es derivado del latín responsus, que significaba "constituirse en garante".

Para las sociedades primitivas, la responsabilidad respondía a un principio universal de equilibrio y eran susceptibles de juicios de responsabilidad tanto los hechos naturales como las conductas humanas. Las relaciones causa-efecto que daban lugar a la responsabilidad comprendían no solo la relación física entre los eventos, sino también una dimensión espiritual que sustentaba el juicio de responsabilidad. Así, los tabúes eran las guías de las acciones humanas y la responsabilidad, materializada en la expiación y el sacrificio, era el medio para recomponer las consecuencias de la conducta indebida.

Con la evolución de las sociedades humanas - distinción entre individuo, grupo, vida privada y pública, y entre las cuestiones divinas y humanas-, se dan conceptos particulares de responsabilidad y aparece la concepción de la responsabilidad propiamente jurídica con dos consecuencias importantes: la ofensa o violación a la norma y la sanción. Se empiezan a distinguir los efectos del quebrantamiento de los órdenes normativos, con lo que las consecuencias de la violación adquieren un carácter independiente y particular (político, jurídico, religioso, moral). En lo que toca a la responsabilidad jurídica, la particularización del orden normativo se refleja en la 
noción de pena como consecuencia de la ofensa a ese orden jurídico particular, que tiene lugar bajo dos condiciones: en primer lugar implica la existencia de un comportamiento social necesario para la comunidad-concretado en la protección de la vida y las estructuras económicas - y en segundo lugar implica la existencia de una autoridad que implementa y ejecuta las normas de la comunidad. Al respecto, Pablo Larrañaga sostiene:

La primera condición nos habla del carácter público de la responsabilidad jurídica en contraposición con la responsabilidad moral, que en principio atañe al ámbito privado, y la segunda apunta a la centralización del poder público, esto es, la vinculación del derecho con el poder del Estado que determina el carácter de la responsabilidad jurídica por su vinculación con las normas de la naturaleza.13

Al organizarse la vida pública mediante normas jurídicas, la noción de responsabilidad jurídica se particulariza según dos esferas más específicas: (i) la responsabilidad política, referida a la existencia de gobernantes y a la gestión pública sobre la base del concepto de interés general; y (ii) la responsabilidad jurídica propiamente dicha, segmentada en dos paradigmas que corresponden a dos funciones del derecho: la protección de la vida y de la integridad física (paradigma penal) y la protección de los bienes económicos (paradigma civil) ${ }^{14}$.

La distinción entre responsabilidad penal y responsabilidad civil fue evolucionando históricamente; sin embargo, su distinción clara solo se logra cuando se advierten dos consecuencias jurídicas distintas para las conductas indeseables: el castigo y la obligación de restitución o compensación; consecuencias jurídicas que nacen a su vez de procesos de estratificación de las relaciones sociales y del derecho. Este último proceso lleva a que el Estado se reserve el derecho de intervenir en las infracciones relacionadas con el interés común por considerar una amenaza al orden social, dejando en libertad para las relaciones de los particulares el campo normativo relacionado con el aspecto económico ${ }^{15}$.

13 Pablo Larrañaga Monjaraz. El ConcePto dE RESPonsabilidad. México D.F.: Editorial Fontamara. (2004).

14 Olga Cecilia González Noriega. Responsabilidad extracontractual del Estado. Una aproximación desde la teoría de la responsabilidad de los clásicos a su carácter de disciplina autónoma del derecho. REVISTA UIS HUMANIDADES 2. 2012.

15 Hugo Caldera Delgado. SISTEMA DE LA RESPONSABILIDAD EXTRACONTRACTUAL DEL ESTADO EN LA CONSTITUCIÓN POLÍTICA DE 1980. Santiago: Editorial Jurídica de Chile. (1982). 
Lo anterior permitió la distinción, desde el punto de vista jurídico, de los dos grandes ámbitos del derecho: el penal y el civil, quedando cada uno con su propia normatividad y desarrollo dogmático, e igualmente se produjo una distinción en cuanto a la forma en que se enfoca la responsabilidad jurídica, diferenciando la responsabilidad penal y civil respecto al ilícito que conlleva la sanción, el objetivo de la sanción, los procedimientos que permiten determinar la sanción y el contenido de la sanción.

\section{Responsabilidad jurídica}

El concepto de responsabilidad desde el punto de vista de la teoría general del derecho ha sido desarrollado con base en las condiciones exigidas en los sistemas jurídicos para imputar consecuencias jurídicas a una determinada conducta. Es un concepto mucho más concreto que la noción de responsabilidad, y hace referencia a las condiciones y consecuencias de la responsabilidad dentro de un marco normativo concreto. En el derecho contemporáneo, el teórico más influyente del siglo xx, Hans Kelsen, identifica las nociones de obligación jurídica y de responsabilidad -siendo su principal aporte frente al concepto de responsabilidad, la forma en que vincula el concepto con el de norma jurídica, especialmente con el de sanción-. Kelsen no desarrolla una teoría de la responsabilidad jurídica, pero su principal aporte al tema reside en el método y en el objetivo que asigna a la ciencia jurídica y en la vinculación directa que hace de las definiciones jurídicas con la noción de la norma16

La responsabilidad se constituye en función de la condición jurídica, es decir que la conducta suponga una sanción. Para Kelsen, las nociones de responsabilidad, deber y obligación jurídica son las mismas; la responsabilidad simplemente la enfoca como una situación normativa referida a la sanción y no a la obligación jurídica que ella conlleva. La responsabilidad tiene una relación muy estrecha con la sanción, en la que es responsable de la conducta quien en virtud de una norma puede ser sancionado por realizar dicha conducta. Esta situación lleva a que el concepto de responsabilidad solo pueda aplicarse en aquellos ordenamientos jurídicos en los que la responsabilidad suponga sancionabilidad, no siendo entonces viable frente a sistemas jurídicos cuyas normas no tienen una función sancionadora, como por ejemplo la responsabilidad directa o responsabilidad por resultado.

Por su parte, Alf Ross hace referencia a la responsabilidad como un sistema. Considera la responsabilidad como exigibilidad en virtud de la cual la persona responde con fundamento en la culpa y responsabilidad como sancionabilidad conforme

16 Id. 
a la cual se le sanciona17. La culpabilidad es un requisito exigido para determinar responsabilidad y la responsabilidad es un presupuesto de la sanción jurídica o el castigo. Las nociones de culpabilidad, responsabilidad y castigo se encuentran estrechamente relacionadas y tienen como fundamento común el haber trasgredido un sistema jurídico.

H.-L. Hart se aproxima al concepto de responsabilidad desde el punto de vista lingüístico, dándole al término varios significados: como capacidad, como causalidad, como deberes propios de un cargo derivados de un rol social, y como sancionabilidad; términos vinculados todos directa o indirectamente con el sentido de responsabilidad como sancionabilidad ${ }^{18}$.

\section{Responsabilidad y orden jurídico}

No existe un sistema jurídico organizado que no tenga como uno de sus ejes centrales el régimen de responsabilidad, entendido como conjunto de normas destinadas a ser ejecutadas por sujetos de derecho.

A la institución de la responsabilidad se le ha considerado como un concepto jurídico fundamental en el marco de la teoría general del derecho. La responsabilidad jurídica se configura cuando un sujeto de derecho se encuentra en la situación de responder por su conducta; esto es, en la situación de observar respecto a otro sujeto una actitud determinada en razón a que su conducta le ha causado perjuicios ${ }^{19}$.

La responsabilidad como sancionabilidad representa el sentido básico de responsabilidad en el derecho; la responsabilidad se exige del individuo para que tengan lugar las consecuencias normativas.

Así mismo, se encuentra íntimamente unida al funcionamiento eficaz del orden jurídico, concebido como un orden de obligación, porque no puede existir obligación sin la consecuente sanción por su violación. La responsabilidad hace posible las obligaciones jurídicas. En la teoría clásica de la responsabilidad, específicamente en el campo del derecho civil, la unión entre derecho y obligación lleva a que no solo se

17 Enrique Gil Botero y Jorge Iván Rincón Córdoba. LOS PRESUPUESTOS DE LA RESPONSABILIDAD AMBIENTAL EN COLOMBIA. Bogotá: Editorial Universidad Externado de Colombia. (2013).

18 Herbert Lionel Adolphus Hart y Genaro R. Carrió. EL CONCEPTO DE DERECHO. Buenos Aires: Abeledo-Perrot. (1961).

19 Jhon M. Arredondo, José G. Obando y Milena Velandia. LA RESPONSABILIDAD SOCIAL EMPRESARIAL Y EL IMPUESTO A LA RENTA PARA LA EQUIDAD (CREE) EN EL INSTITUTO COLOMBIANO DE BIENESTAR FAMILIAR (ICBF) DE LA CIUDAD DE PEREIRA. Tesis de maestría. Universidad de Manizales. (2017). 
pueda hablar de deber desconocido, sino también del perjuicio cometido; así, en la responsabilidad siempre debe estar presente la relación entre el autor que desconoce la obligación jurídica y quien sufre el daño por el hecho.

\section{La responsabilidad en el ámbito del derecho civil}

\section{La responsabilidad civil como fuente de obligaciones}

La obligación, desde el punto de vista jurídico, es considerada como el vínculo jurídico que se establece entre dos personas, en virtud de la cual un sujeto activo (acreedor) espera un determinado comportamiento (prestación) susceptible de ser valorado pecuniariamente a cargo de otro sujeto llamado deudor, quien se encuentra obligado a realizar la prestación y a resarcir los daños o perjuicios ocasionados por su incumplimiento. Su principal característica es su objeto, que puede consistir en una conducta o prestación a realizar por el deudor en beneficio del acreedor.

Para el profesor Tamayo, "la responsabilidad civil engloba todos los comportamientos ilícitos que por generar daño hacen recaer en cabeza de quien los causó la obligación de indemnizar"20. La responsabilidad civil tiene un carácter esencialmente reparador; tiene por objeto principal la reparación, consistente en restablecer el equilibrio roto por el autor del daño.

Existen unos elementos comunes y esenciales de toda forma de responsabilidad: la conducta realizada por el acto del daño, el daño cierto, personal y antijurídico, y el nexo causal entre la conducta y el daño.

\section{Manifestaciones de la responsabilidad}

En el campo del derecho civil, según el mismo concepto, la responsabilidad ha tenido dos manifestaciones claras: la contractual y la extracontractual. El perjuicio puede emanar de un hecho cualquiera, realizado sin que exista vínculo contractual con el civilmente responsable y la víctima, o puede provenir del incumplimiento de un contrato.

La distinción anterior se refiere al derecho que es violado y así, si la lesión recae sobre un derecho subjetivo absoluto, da lugar a la responsabilidad civil extracontractual; si la lesión recae sobre derechos de crédito que nacen de los contratos, surge la responsabilidad contractual. De ahí que la doctrina denomina responsabilidad

20 Javier Tamayo Jaramillo. ¿Hasta dónde se puede objetivar la responsabilidad civil? Coord. Marcela Castro Cifuentes. DERECHO DE LAS OBLIGACIONES. Bogotá: Ediciones Uniandes. (2010). Págs. 295-314. 
contractual a la que nace del incumplimiento o cumplimiento defectuoso de la obligación del deudor, y responsabilidad extracontractual (o aquiliana) a la que surge de las lesiones a los derechos absolutos.

\section{La responsabilidad civil en el ordenamiento jurídico colombiano}

En nuestro ordenamiento jurídico, la obligación de reparar respecto a la responsabilidad extracontractual se encuentra regulada por los artículos 2341 a 2360 del Código Civil. Se legisló solamente de la responsabilidad de la persona física y no se proveyó sobre la responsabilidad aquilina del sujeto jurídico. Esa sí como la doctrina y la jurisprudencia empiezan a propugnar la aplicación a los entes jurídicos de algunas normas del derecho privado: los artículos 2347 y 2349 del Código Civil, reguladores de las relaciones entre personas naturales.

La Corte Suprema de Justicia, en sentencias de octubre 26 de 1896 y octubre 20 de 1998, tomó el artículo 2347 del Código Civil sobre responsabilidad indirecta que estaba circunscrito a las personas naturales para llevarlo al campo de las personas jurídicas de derecho privado y público ${ }^{21}$.

Se aceptó jurisprudencialmente la aplicabilidad de las normas del Código Civil sobre responsabilidad extracontractual a las personas jurídicas y privadas, imponiéndoles primero una responsabilidad indirecta con fundamento en los artículos 2347 y 2349 del Código Civil. Posteriormente, se fundó la responsabilidad directa aplicando lo dispuesto en el artículo 2841 del Código Civil, y luego se creó la responsabilidad por falla del servicio de las personas de derecho público con la tesis organicista en relación con las clases de personas morales, públicas y privadas.

La responsabilidad inicial de las personas morales de derecho público y de derecho privado a causa de las culpas cometidas por funcionarios o dependientes en ejercicio de sus funciones, o que con ocasión de ella sí causaban daños a terceros, fue la "responsabilidad indirecta". Se reconoció esta responsabilidad partiendo de que la persona jurídica estaba obligada a elegir bien sus agentes y a vigilarlos de manera cuidadosa por ser sus dependientes o subordinados, de tal manera que si incurren en culpas en ejercicio de su cargo, esta se proyecta hacia la entidad pública de acuerdo con lo previsto en los artículos 2341 y 2349 del Código Civil.

En materia de responsabilidad del Estado, la jurisprudencia civil aplicó desde un principio los artículos 2341 y 2349 del Código Civil relacionados con la responsabilidad

21 Mónica Lucía Fernández Muñoz. La culpa en el régimen de responsabilidad por el hecho ajeno. Estudios socıo-JURíDicos 1. 2003. Págs. 230-249. 
directa e indirecta, en su orden, para configurar lo que por sus hechos dañosos pudiera caberles a los entes públicos

En el campo de la responsabilidad civil, busca restablecer el equilibrio patrimonial roto por la conducta del causante que afecta el patrimonio del perjudicado; la responsabilidad civil gira alrededor del concepto de daño que exige una compensación. El Código Civil colombiano establece en su artículo 2343: "Es obligado a la indemnización el que hizo el daño y sus herederos".

El enfoque moderno en materia de responsabilidad civil busca proteger a las víctimas o los perjudicados, de ahí que se hayan creado mecanismos en el ámbito constitucional, legal y jurisprudencial que permitan al perjudicado hacer efectivos los derechos que le han sido vulnerados y a recibir la indemnización por esa violación.

\section{La responsabilidad de la Administración Pública}

\section{Evolución del principio de responsabilidad de la Administración Pública}

\section{Primer momento}

La responsabilidad extracontractual del Estado se desprende de la clásica responsabilidad civil. Sin embargo, ha tenido una evolución teórica muy importante partiendo de la misma existencia de responsabilidad de la Administración, hasta lograr abandonar los fundamentos legales de la legislación civil y tener su propio fundamento legal en la Constitución Política.

En cuanto a la existencia de la responsabilidad del Estado, en un primer momento no se consideró que el Estado fuera responsable de los daños que causara por su actividad en aplicación de la teoría de soberanía, entendida como el poder absoluto y perpetuo que justificaba la irresponsabilidad del Estado. El soberano disponía libremente de los bienes de los ciudadanos y solo era responsable de sus actos frente a la divinidad de la que emanaba su poder. El absolutismo de los monarcas, en quien se concentraban todos los poderes, impedía que los súbditos ejercieran acciones tendientes a lograr el resarcimiento por los perjuicios que se le causaran por el actuar del soberano.

En este periodo, los conceptos de responsabilidad y soberanía se excluían. Anota el profesor Duguit: 
Es evidente que tomadas en sí las dos nociones de responsabilidad y de soberanía son antinómicas, porque si el Estado se considera soberano, no puede admitirse que sea responsable y si se afirma que es responsable, no puede admitirse que sea soberano. O la soberanía es nada, o ella es, como se ha dicho, ese rasgo de voluntad que no se determina sino por sí misma, es decir, que no puede limitarse por un elemento extraño, ni sometido a obligaciones sino en la medida en que es consentida. De ahí resulta que una persona soberana no puede ser responsable de sus actos, esto es, sometida a una obligación que se imponga a ella desde el exterior, o por lo menos no puede serlo en la medida en que lo quiera. ${ }^{22}$

Al ser el monarca soberano, sostiene el profesor Irisarri, no podía obrar erróneamente, ni causar perjuicio alguno, pues "el Estado se identificaba con su monarca"23, por lo que no se concebía la posibilidad de que fuera responsable si obraba en forma dañosa.

El concepto de soberanía evolucionó de acuerdo con las ideologías imperantes. En un principio, se impuso la concepción teocrática, teoría que fundamentaba el poder del soberano en su origen divino. La imputación de responsabilidad patrimonial al soberano por los daños resultantes de su actuación pugnaba con la tradición multisecular, que a través de una combinación de las protestas imperial romana y de la concepción teocrática del poder del monarca, encontró su expresión en el principio formulado por los juristas ingleses: "el rey no puede hacer lo ilícito"24.

\section{Segundo momento}

En el siglo XVIII, surgieron las teorías democráticas que justificaron las nuevas estructuras del poder político, en las que la voluntad general se constituyó como la máxima expresión del poder en la sociedad política y ella lo justificaba todo. Las concepciones teocráticas y democráticas del poder político tuvieron como fundamento la teoría de la soberanía, entendida como el poder absoluto y perpetuo que justificaba la irresponsabilidad absoluta del Estado. El fundamento legal que sostuvo la irresponsabilidad del soberano, así como las causas que llevaron a su reconocimiento, fue

22 Graciela Cortés Urueta. CONTROL PREVIO DE CONSTITUCIONALIDAD SOBRE LAS REFORMAS constitucionales. Tesis de maestría. Universidad de Manizales. (2019).

23 Rafael Altamira y Crevea. HISTORIA DE ESPAÑA Y DE LA CIVILIZACIÓN ESPAÑOLA. Barcelona: Editorial Herederos de Juan Gili. (1911).

24 Eduardo García de Enterría y Tomás Ramón Fernández. CURSO DERECHO ADMINISTRATIVo. томо 1. Madrid: Editorial Civitas (1977). Pág. 361. 
común en todos los ordenamientos jurídicos, variando en cuanto a la forma en que se dio la ruptura con el principio de irresponsabilidad del Poder Público.

Fueron diversas las teorías que dieron fundamento a la responsabilidad del Estado, nos señala el profesor argentino Julio Altamira ${ }^{25}$ en su estudio sobre la responsabilidad del Estado por daño. Una de ellas es la teoría de la ficción propuesta por Savigny, en la que se admite responsabilidad de la Administración derivada de los actos lícitos ejecutados dentro de los límites estatutarios, negando toda posibilidad de responsabilidad proveniente de actos ilícitos, por considerarse estos ejecutados por un representante fuera de los límites del mandato, de tal suerte que no es posible castigara una persona jurídica por los delitos cometidos por su representante.

Posteriormente, surgió la teoría organicista que reconoce a la Administración Pública como un gran órgano del cual hacen parte sus funcionarios, de tal suerte que si el funcionario comete una falta, es la Administración quien la comete y como tal se le imputa.

Otra teoría propuesta fue la teoría de la proporcionalidad de cargas, formulada por Teissier ${ }^{26}$, en la que se sostenía que la equivalencia e igualdad de cargas lleva a determinar responsabilidad de la Administración por sus actos y por los de sus agentes, distribuyendo los daños que se ocasionen. Si el Estado perjudica a un habitante haciéndolo sufrir un daño que se considera injusto frente a los demás ciudadanos, debe indemnizarlo para no romper el principio de equidad, de igualdad, que ampara a todos los ciudadanos. Esta teoría, nos informa el profesor Álvaro Castro27, posteriormente se aplicó en el derecho alemán como criterio de la carga desigual o especial del particular sacrificio y está basada en la Declaración de los Derechos del Hombre y del Ciudadano, que sostuvo en su artículo 78 que "unos ciudadanos no deben sufrir más que otros las cargas impuestas en interés de todos".

El mismo profesor Altamira ${ }^{28}$ propuso la teoría del bien común, en la que el fundamento de la responsabilidad del Estado es el bien común de toda la comunidad, de tal suerte que ella no puede estar satisfecha si uno de los miembros de esa comunidad sufre daños provenientes de la actividad de la Administración, por lo tanto es obligatoria su indemnización.

25 Lizandro Alfonso Cabrera Suárez. El control de convencionalidad y la protección de los derechos humanos en Colombia. DIXI 19. 2014. Págs. 53-70.

26 Rafael Altamira y Crevea, supra, nota 24.

27 Álvaro Castro Morales. Ejecución de la pena de prisión de adultos en Alemania: análisis de las leyes estaduales a la luz de la Ley Federal de 1976 y la jurisprudencia del Tribunal Constitucional Federal Alemán (BVerfG). DERECHO PUCP 82. 2019. Págs. 281-313.

28 Rafael Altamira y Crevea. HISTORIA DE LA PROPIEDAD COMUNAL. Madrid: J. López Camacho. (1890). 


\section{Tercer momento}

Tiempo después, al justificarse el Estado como la organización con capacidad de prestar servicios públicos, surgió la noción de actos de servicio público y actos ajenos al servicio público. Esta concepción tuvo como instrumento la intervención del Estado para la realización de sus fines, cuyo resultado lógico fue que con la intervención del Estado se ocasionaran perjuicios al patrimonio de los administrados.

Así surgió la tesis de la falla del servicio, como proyección del deber ser del Estado de prestar a la comunidad los servicios públicos y responder si causan daños en su prestación. El intervencionismo del Estado se constituyó así en la fuente que permitió administrar la responsabilidad extracontractual del Estado.

Se hace distinción entre la responsabilidad proveniente de la falla del servicio y la proveniente de la falla personal del agente. El Estado responde si al cumplir su función causa un daño, y se considera falta del agente cuando este se extralimita en sus funciones y comete la falta.

Duguit $^{29}$ sustenta la teoría de la responsabilidad por riesgo argumentando que la responsabilidad de la Administración surge frente al daño o perjuicio ocasionado a un particular por el funcionamiento de los servicios públicos.

\section{El proceso de afirmación de la responsabilidad de la Administración}

En los sistemas anglosajones, la irresponsabilidad de la Corona resultaba de dos principios; por un lado, el "the King can do not wrong" ("el rey no puede hacer el mal") en el plano material y, por otro, la inmunidad judicial de la Corona (non-suability) desde el punto de vista procesal, que hacía depender la litis de una petición formal de derechos a la Corona, pero quedaban excluidos de su ámbito las reclamaciones por los daños extracontractuales. El principio de irresponsabilidad de la Corona eliminaba cualquier posibilidad de exoneración de sus agentes al prohibir incluso que se invocara por ellos el cumplimiento de órdenes recibidas como fuente de daños. Según las reglas del common law, el peso de la responsabilidad por daños recaía íntegramente sobre los propios funcionarios.

Este sistema de irresponsabilidad de la Corona lo mantuvo la administración abstencionista; sin embargo, empezó a tener problemas por la mayor intervención del Estado y porque dada la cuantía de los daños ocasionados ya no era posible que fueran resarcidos con el patrimonio de sus agentes, autores materiales de los daños.

29 Olga Cecilia González Noriega, supra, nota 15. 
La ruptura del principio del common law de irresponsabilidad del Estado se dio con una reforma legislativa: Crown Proceedings Act de 1947, que sometió a la Corona a la misma responsabilidad de las personas privadas con plena edad y capacidad tanto en razón a los daños cometidos por sus funcionarios, como por el incumplimiento de las obligaciones para con sus funcionarios.

El sistema norteamericano inicialmente estuvo dominado por el principio de "the King can do not wrong". Dado el aumento de las reclamaciones por indemnización de los daños ocasionados por la Administración, el Congreso creó un órgano asesor especializado (Court of Claims) del que surgió un tribunal con competencia para decidir sobre las reclamaciones de pequeñas cuantías, y posteriormente se aprobó un proyecto de ley de carácter general (Federal Tort Claims Act en 1946), mediante el cual se reconoció la responsabilidad del Estado.

Si bien en estos ordenamientos se empieza a reconocer, aunque tímidamente, la responsabilidad del Estado, no ocurrió lo mismo en Europa, especialmente en Alemania y en Francia, con ordenamientos jurídicos en los que -desde el primer momento- se lucha contra la irresponsabilidad del Estado, criterios que sirvieron de fuente directamente del actual sistema de responsabilidad.

En Alemania, la responsabilidad patrimonial del Estado (Staatshaftung) se empieza a formular como responsabilidad indirecta por los actos ilícitos en que incurrían los funcionarios y agentes del Estado; principio formulado en la Constitución de Weimar en su artículo 131: "Si en el ejercicio de la potestad pública a él confiada el funcionario infringe los deberes que el cargo le impone frente a terceros, la responsabilidad alcanza por principio al Estado o a la Corporación a cuyo servicio se hallase el funcionario"30, posteriormente establecida en la Ley Fundamental de Bonn.

Junto a esta teoría de responsabilidad patrimonial del Estado, surge la llamada teoría de la indemnización de derecho público que procede cuando se dan intervenciones conforme a derecho (rechtmässige Eingriffe), específicamente en el caso de las expropiaciones o traspaso forzoso de derechos y en el que procede la indemnización del Estado por el sacrificio de la comunidad de sus intereses y ventajas.

Al no ser suficientes las teorías anteriores para la cobertura de los daños ocasionados a los ciudadanos, en especial cuando estos provenían de acciones de la Administración en los que no existía culpa o de intervenciones amparadas por la ley o en virtud del interés general, surge como producto de la doctrina y jurisprudencia una tercera fórmula de cobertura, que acoge los daños resultantes de intervenciones antijurídicas sin culpa y de situaciones de riesgo creadas por la Administración.

30 Eduardo García de Enterría y Tomás Ramón Fernández, supra, nota 25, pág. 361. 
Así, se tenían tres tipos de responsabilidad en Alemania: la responsabilidad propiamente dicha ligada a una actividad ilícita productora del daño; la indemnización de derecho público que cubre los daños ocasionados lícitamente, y la doctrina del riesgo y las intervenciones antijurídicas sin culpa y que fueron regulados posteriormente por la ley.

En Francia, igualmente, se presentó una importante evolución en relación con la responsabilidad de la Administración. Inicialmente, imperaba el principio de irresponsabilidad del Estado excluyéndose el deber de indemnizar. La única garantía que se ofrecía era la responsabilidad directa del funcionario, autor del daño, exigible de acuerdo con las normas del derecho civil. La responsabilidad directa del funcionario evolucionó en el sentido de ser exigible para imputar responsabilidad al funcionario de una autorización administrativa previa, considerada como requisito para poder demandar al funcionario por la vía civil. De esta intervención administrativa inicial surge la responsabilidad patrimonial de la Administración. La jurisprudencia del Consejo de Estado francés reconoce la responsabilidad del funcionario siempre que se pudiera demostrar la existencia de una falta personal del agente como causante del daño, permitiendo en los eventos en los que se reputaba una falla del servicio dirigir la acción contra la Administración.

Inicia así la evolución de la responsabilidad patrimonial de la Administración al restringirse la responsabilidad personal del funcionario a su falta personal causante del daño, ajena de toda relación de servicio o con intención manifiesta de causar daño, con lo que se acepta la responsabilidad de la Administración por los daños ocasionados por sus agentes cuando estos no tengan carácter de faltas personales. Toda negligencia, error u omisión relacionada con el servicio público es inseparable de este, constituye una faute de service y la Administración debe entrar a reparar el daño sufrido como responsable del servicio.

Posteriormente, con el Fallo Blanco de 1873 se establece el principio general de responsabilidad de la Administración, con autonomía e independencia de los principios establecidos en el Código Civil que regula las relaciones entre particulares. Así, continúa su evolución a tal punto que se extiende la responsabilidad de la Administración a todo tipo de servicios y daños que le sean imputables por ser producidos por personas sometidas a su autoridad o por cosas que están bajo su guarda, y en los que existe un nexo causal directo entre la actividad del ente público y el perjuicio sufrido ${ }^{31}$.

31 Jaime Gamboa y Jaime Orlando Santofimio. León Duguit y su doctrina realista, objetiva y positiva del Derecho en las bases del concepto de servicio público. REVISTA DIGITAL DE DERECHO ADMINISTRATIVo 5. Enero-junio 2011. Págs. 43-86. 
En el derecho español, de una situación de irresponsabilidad absoluta del Estado, incluso cuando el daño provenía de sus agentes, se dio paso al reconocimiento legislativo expreso del principio de la responsabilidad de la Administración; se le otorgó además rango constitucional a la responsabilidad subsidiaria de la Administración y por ende su obligación de indemnizar cuando el daño provenía de un funcionario que incumplía sus deberes en ejercicio de su cargo.

Con la expedición de la Ley de Expropiación Forzosa en 1954, se consagra en términos más amplios la responsabilidad patrimonial de la Administración, dando una gran amplitud al principio cuyo alcance se extiende a todas las esferas administrativas. Estableció el artículo 121 de la Ley de Expropiación Forzosa la indemnización por las lesiones sufridas por los particulares en sus bienes y derechos como consecuencia del funcionamiento normal o anormal de los servicios públicos ${ }^{32}$.

Posteriormente, mediante leyes generales se establece la cláusula general de cobertura patrimonial de los administrados (Ley 27 de diciembre de 1956), una fórmula legal sobre la cual se edifica todo el sistema español de responsabilidad civil de la Administración y que ha tenido abundantes pronunciamientos del Consejo de Estado al respecto.

Este planteamiento fue tomado por la Constitución de 1978, que asumió la cláusula general de responsabilidad de la Administración estableciendo el derecho de los particulares a ser indemnizados por toda lesión que sufran en sus bienes y derechos que sea consecuencia del funcionamiento de los servicios públicos. Se consagra así la responsabilidad directa de la Administración no solo por los daños ilegítimos que son consecuencia de una actividad culpable de la Administración o de sus agentes como consecuencia del funcionamiento anormal de los servicios públicos, sino también por los daños producidos por toda actividad lícita de la Administración o funcionamiento normal del servicio público que causa daño.

\section{FUNDAMENTOS DE LA RESPONSABILIDAD DEL ESTADO}

En Francia, el Tribunal de Conflictos reconoce por primera vez la autonomía de la responsabilidad del Estado, no regida por normas contenidas en el Código Civil aplicables a las relaciones entre los particulares, sino a través de reglas especiales, cuya elaboración correspondía al juez administrativo a través del famoso Fallo Blanco, considerado como la piedra angular de todo el derecho administrativo.

32 Eduardo García de Enterría y Tomás Ramón Fernández, supra, nota 25, pág. 369. 
En el Fallo Blanco, se declaró que "la responsabilidad que puede incumbirle al Estado por los daños causados a los particulares como consecuencia de los hechos de las personas que emplea para el servicio público no puede estar regida por los principios establecidos en el Código Civil para las relaciones entre particulares"33.

Del contenido del Fallo Blanco se destacan dos elementos, comentan los tratadistas Long, Weil, Braibant:

La razón básica para sustraer la responsabilidad del Estado de la esfera propia del Código Civil fue la necesidad de conciliar intereses de la colectividad en la correcta prestación de los servicios públicos con los de los particulares que pudieran verse afectados por una falla en la correcta prestación; y de otra parte, el carácter excepcional que el fallo quiso darle a la responsabilidad del Estado por fallas en la prestación de los servicios públicos, en la que la responsabilidad no es general ni absoluta, con los cuales quiso expresar que la autonomía de la responsabilidad del derecho administrativo implicaba menor favorabilidad para los particulares frente a las soluciones que daba el Código Civili ${ }^{34}$

Si bien el Fallo Blanco proclama la autonomía de la responsabilidad del Estado, esta se estructuró sobre el elemento de culpa como se había venido haciendo en la responsabilidad civil de los particulares. Para imputar responsabilidad al Estado, era necesario demostrar la existencia de la culpa, demostrar que el perjuicio sufrido por la víctima era causado por un error de conducta imputable al Estado.

A partir de Fallo Blanco, se consagró la responsabilidad del Estado independientemente de que estuviera estatuida en una ley o fuera consecuencia de su actividad de poder o de gestión en la falla del servicio público. El Estado es responsable cuando se ha excedido en el ejercicio de sus poderes legales o cuando la prestación del servicio público ha sido defectuosa. Aparece la noción de servicio público como función principal del Estado, y se presenta su responsabilidad cuando el servicio no se ha prestado, se ha prestado mal o su funcionamiento ha sido tardío, inadecuado o defectuoso.

33 Lucas A. Piaggio. LA POTESTAD REgLAMENTARIA DE LA ADMINISTRACIÓN EN UN RECIENTE FALLO DE LA CORTE SUPREMA DE JUSTICIA DE LA NACIÓN. Buenos Aires: Thomas Reuters. (2019).

34 Erika Mayerly Duarte Villarreal. APLICABILIDAD DE LA CARGA DINÁMICA DE LA PRUEBA EN EL RÉGIMEN DE RESPONSABILIDAD SUBJETIVA DEL ESTADO COLOMBIANO. Trabajo de grado. Universidad Católica de Colombia. (2017). 
Para su aplicación, primero se tomaron las normas contenidas en el Código Civil (artículos 2347 y 2349) que regulaban la responsabilidad indirecta de una persona por las acciones realizadas por quienes estuvieran bajo su cuidado y, por analogía, se extendieron a la responsabilidad del Estado frente a las culpas de sus agentes.

Por mucho tiempo, la responsabilidad del Estado fue una responsabilidad civil extracontractual, basada en la regla básica de la responsabilidad directa contenida en el artículo 2341 del Código Civil. Según la consideración de que la culpa de los agentes es la misma culpa del Estado por ocurrir en el desempeño de funciones públicas, se empieza a hablar de la responsabilidad directa de la Administración.

El reconocimiento de la responsabilidad patrimonial del Estado se dio cuando se abandonó definitivamente la culpa como fundamento básico de la responsabilidad y comenzó a hablarse de responsabilidad por falla del servicio público, con lo que se apartó de las normas que hasta ese momento eran aplicadas para imputar responsabilidad al Estado: el Código Civil.

Sin embargo, la autonomía de las normas que regulaban la responsabilidad de la Administración dada por el Fallo Blanco no fue total. Si bien existen numerosos puntos en los que difieren la responsabilidad estatal y la civil, existen otros en los que la aproximación entre las teorías civilistas y administrativistas es clara; por ejemplo, en derecho administrativo no toda falta compromete la responsabilidad de la Administración, fundada en algunos casos en la igualdad de las cargas públicas, teoría que no tiene su equivalente en derecho civil; igual, el funcionario por la simple falla del servicio no es personalmente responsable, mientras que si se considera como empleado sujeto a las normas de derecho privado, sí lo sería.

En otros asuntos, es clara la aproximación de las teorías civilistas y administrativistas de responsabilidad. Por ejemplo, el reconocimiento de la responsabilidad del Estado por los actos cometidos por sus agentes que desobedecen las órdenes recibidas en ambos regímenes se aplica en la teoría del "aviso de funciones".

Sobre la originalidad de la responsabilidad del Estado, manifiesta el profesor Vedel: "[...] la responsabilidad pública no presenta, a pesar de las diferencias, ninguna originalidad del fondo en relación con la responsabilidad privada. Es exacto que la autonomía del derecho administrativo es mucho más perceptible si se examina la teoría de los contratos administrativos que si se examina a la de la responsabilidad"35.

Se diferenciaba así cuando los daños provenían de un acto personal del funcionario y aquellos en los que la culpa estaba directamente ligada al ejercicio de una función propia del Estado. La responsabilidad por falla del servicio se extendió

35 Georges Vedel. DERECHO ADMINISTRATIVo. Trad. Juan Rincón Jurado. Madrid: Editorial Aguilar. (1980). 
a todo el régimen jurídico de responsabilidad patrimonial del Estado, que envuelve una responsabilidad directa y anónima a cargo del Estado en la que importa demostrar que tuvo lugar una actuación irregular de la Administración y no una culpa personal del funcionario.

Si bien la teoría de la falla del servicio logró un gran avance en cuanto a la imputación de la responsabilidad del Estado, se empiezan a dar situaciones que no tienen cabida en el concepto de falla del servicio, pero en las que era imperioso que el Estado respondiera por los daños sufridos, dada la dificultad que se presentaba al probar la falla del servicio o de su vínculo causal con el perjuicio. Así se empieza a admitir la presunción de la falla del servicio en unos casos y en otros, la responsabilidad del Estado cuando pese a haber actuado bien, esto es, sin haber falla en el servicio, causaba un perjuicio que la víctima no estaba en la obligación de soportar.

\section{EVOLUCIÓN DE LA RESPONSABILIDAD EXTRACONTRACTUAL DEL ESTADO EN COLOMBIA}

En Colombia, el régimen de responsabilidad del Estado tuvo una evolución similar a la que se dio en los países europeos, siguiendo para su desarrollo el modelo francés. Solo hasta finales del siglo XIX se admitió responsabilidad del Estado y creación de la jurisprudencia, ya que no existía norma expresa que determinara la responsabilidad del Estado por los daños ocasionados en ejercicio de funciones públicas a los particulares.

\section{Responsabilidad declarada por la Corte Suprema de Justicia}

A mediados del siglo Xx, la Corte Suprema de Justicia, Sala de Negocios Generales y Sala de Casación Civil, en sentencias de octubre 20 de 1998, octubre 22 de 1896 y julio 19 de 1916, estableció la responsabilidad indirecta del Estado bajo el argumento de que como persona jurídica estaba obligada a las reparaciones civiles por los daños que resultaran de la mala elección o falta de vigilancia mientras no fuera probada falta de culpa ${ }^{36}$.

36 Pamela Prado López. Crítica a la configuración de la responsabilidad civil de la empresa principal y de la empresa usuaria en la Ley N 20.123. JORNADAS NACIONALES DE DERECHO CIVIL. Valparaíso, Chile. 2007. 
En Sentencia de junio 30 de 1962, la Sala de Casación Civil, con ponencia del magistrado Dr. José J. Gómez, hizo un estudio del problema en los siguientes términos:

Se reconoció esta responsabilidad partiendo del principio de que la persona jurídica se halla obligada a elegir a sus agentes y a vigilarlos de manera cuidadosa, ya que son sus dependientes o subordinados, de suerte que si incurren en culpa, ejerciendo sus cargos, esta se proyecta sobre la entidad jurídica la forma prevista en los artículos 2347 y 2349 del Código Civil.

Esta teoría se fundó en la culpa cometida por los funcionarios cuando causaban daños a terceros, o con ocasión de sus funciones se proyectaba sobre la Administración en razón a su obligación de elegir y vigilar a sus agentes por ser sus dependientes. Es esta una responsabilidad extracontractual indirecta.

En relación con las personas jurídicas contempladas en los artículos 2347 y 2349 del Código Civil de responsabilidad indirecta, la jurisprudencia halló insuficientes los fundamentos de esta forma de responsabilidad por la inaplicabilidad de los deberes de escogimiento y control. En Sentencia del 21 de agosto de 1939, la Corte Suprema de Justicia empieza a estructurar la responsabilidad directa de la persona jurídica, apartándose en las culpas in ilegendo e in vigilando, y acogiendo la tesis de que si un funcionario actúa como tal, las acciones, omisiones y culpas en que pueda incurrir se reputan como acciones, omisiones y culpas del Estado, aplicando como soporte normativo el artículo 2341 del Código Civil relacionado con la responsabilidad personal y directa de las personas por los delitos y las culpas. Para la Corte, el Estado y sus agentes constituyen una unidad de tal modo que la culpa personal del agente compromete a la persona jurídica del Estado.

La culpa del derecho común, sostuvo la Corte en esta sentencia, localizada en un agente infractor, según la tesis de la responsabilidad directa, vino a radicarse en el Estado con lo cual se configura la llamada culpa de la administración.

Posteriormente, surge la tesis de falla del servicio como proyección al deber del Estado de reparar los daños que cause a los ciudadanos el funcionamiento inadecuado de los servicios públicos, así se señaló en Sentencia del 21 de agosto de 1939. En ese funcionamiento inadecuado, quedaban incluidas las hipótesis de que el servicio no funcionó, funcionó mal o funcionó en forma tardía. La culpa del agente infractor, según la tesis de la responsabilidad directa, se radicó en cabeza del Estado, configurándose la llamada "culpa de la administración". La Corte apeló al artículo 2341 del Código Civil para sustentar esta tesis frente a la responsabilidad civil de las personas públicas. 
La teoría de la responsabilidad directa tuvo una variante que limitaba su aplicación: la teoría organicista, cuya idea central fue desarrollada por la Corte Suprema de Justicia en fallo de casación de febrero de 1958 y que fue explicada bajo el siguiente argumento:

Las personas jurídicas obran también mediante órganos, El órgano es la persona o conjunto de personas encargadas del cumplimiento de una función colectiva propia de la organización y fines a que se dedica la persona jurídica; por ser un órgano propiosy necesario para el cumplimiento de los fines [...] por ser parte integrante de su existencia y constitución, se miran los actos de semejante órgano como actos propios y directos de la personas jurídica.

\section{Responsabilidad declarada por el Consejo de Estado}

A partir de 1938, admite la Corte que en determinados casos se le aplica al Estado la responsabilidad por actividades peligrosas, bajo el postulado señalado en el artículo 2356 del Código Civil. Posteriormente, la Corte Suprema de Justicia unifica sus criterios en materia de responsabilidad del Estado y aplica la tesis de la falla del servicio público, asimilándola a la culpa extracontractual hasta que mantuvo la competencia para conocer y juzgar los casos de responsabilidad patrimonial del Estado.

A partir de la Ley 167 de 1941 que expidió el Código Contencioso Administrativo, se le asignó competencia a la jurisdicción de lo contencioso administrativo de conocer los procesos adelantados contra el Estado por daños causados por trabajos públicos, continuando los demás asuntos relacionados con la responsabilidad del Estado en cabeza de la jurisdicción ordinaria.

A partir de la expedición del Decreto 528 de 1964, se modifican las funciones de la jurisdicción de lo contencioso administrativo y se le otorga la competencia en la definición de las controversias sobre responsabilidad del Estado, asumiendo de plano el conocimiento de todos los hechos dañosos atribuidos al Estado.

Tan pronto se fundó, tuvo cabida el régimen de derecho común de la responsabilidad administrativa sobre el concepto de falla del servicio público, el régimen intermedio de falla o falla presunta y los regímenes objetivos en los que la falla no entra en juego. 
A partir de la reforma constitucional de $1936^{37}$ y de la expedición del Código Contencioso Administrativo de 1941, se aplica el principio de que la actividad del Estado es de naturaleza jurídica distinta de la actividad de los particulares, cuyo fundamento es la satisfacción de los intereses de la colectividad. Se estructuran las nociones de responsabilidad de las entidades de derecho público, con lo que se crea un sistema jurídico regido por normas sustantivas y adjetivas de derecho público sometidas al control de la jurisdicción de lo contencioso administrativo.

En 1947, el Consejo de Estado fundamenta la teoría de responsabilidad del Estado no solo en las vías de hecho o abuso del poder, sino también en los perjuicios causados por la operación administrativa, cuya ejecución adolece de falta y puede el perjudicado demandar al Estado la reparación del daño.

En Sentencia de septiembre 30 de 1960, el Consejo de Estado se refiere a la separación definitiva de las normas del Código Civil en materia de responsabilidad del Estado y aboga por la aplicación de normas de derecho público. Sostuvo que:

La responsabilidad del Estado no puede ser estudiada y decidida con base en las normas civiles que regulan la responsabilidad extracontractual, sino a la ley de los principios y doctrina del derecho administrativo, en vista de las diferencias sustanciales existentes entre este y el derecho civil, dadas las materias que regulan ambos derechos los fines perseguidos y el plano en que se encuentran regulados.

La anterior afirmación es sostenida dada la materia especial que regula el derecho administrativo, diferente a la tratada en el derecho civil: las relaciones jurídicas de las entidades públicas entre sí y con respecto a los particulares y administrados que tienen por objeto la satisfacción de las necesidades de la comunidad y gozan de especiales prerrogativas para lograr sus fines.

La posición del Consejo de Estado adquirió mayor solidez con la expedición del Decreto 01 de 1984 Código Contencioso Administrativo, que incluyó disposiciones en materia de responsabilidad del Estado y de los funcionarios por daños ocasionados en el ejercicio de sus funciones que les sean imputables a título de dolo o culpa grave, y se consagró la llamada "acumulación de responsabilidades" que permite demandar en forma conjunta a la entidad pública y al funcionario para obtener la indemnización de perjuicios, todo ello acogiendo lineamientos doctrinales y jurisprudenciales. El Consejo de Estado funda la responsabilidad del Estado en que "todo perjuicio

37 José Félix Patiño Restrepo. LECcIONES DE CIRUgÍA. Bogotá: Editorial Médica Panamericana. (2000). 
emanado del Estado debe ser reparado, ya que constituye una violación a la igualdad de los ciudadanos frente a las cargas públicas".

En Sentencia de octubre 28 de 1976, se sostuvo que la responsabilidad extracontractual de la Administración "encuentra su respaldo jurídico en las normas de la Constitución Política, especialmente en las que conforman el Título Tercero de dicho estatuto que trata de los derechos civiles y garantías sociales, constitutivos del objetivo fundamental de la organización de la Nación como Estado de Derecho".

Siguió después el abandono de las reglas contenidas en los artículos 2341 y siguientes del Código Civil como base de la responsabilidad aquiliana del Estado y el afianzamiento en su reemplazo de la figura de la falla del servicio.

En Sentencia de mayo 5 de 1978, sostuvo el Consejo de Estado que "cuando el Estado, en desarrollo de sus funciones incurre en la llamada Falta o Falla de la Administración, trátese de simples actuaciones administrativas, omisiones, hechos $u$ operaciones administrativas, se hace responsable de los daños causados al administrado".

En el desarrollo jurisprudencial de la teoría de la falla del servicio como fundamento de la responsabilidad del Estado, la jurisprudencia del Consejo de Estado y de la Corte Suprema de Justicia tiene elementos estructurales similares. Existen puntos de contacto como la sustitución de la culpa individual por la culpa anónima; la presunción de la culpa cuando el servicio no funciona, funciona mal o en forma tardía; la necesidad de probar como presupuesto de la responsabilidad la actuación administrativa, el daño y la relación o nexo causal; y los medios con los que cuenta la administración para exonerase de culpa.

El Consejo de Estado, durante más de veinte años, reafirmó la noción de falla de servicio como fundamento de la responsabilidad patrimonial del Estado, cobijando con esta teoría todos los eventos en los que la Administración incurría en falta, retardo u omisión en el desarrollo de sus funciones. Sin embargo, dado que no todos los casos en los que se reclamaba el resarcimiento de los perjuicios por la acción u omisión podían ser reconocidos bajo este régimen de responsabilidad, empezó esta Corporación a formular alternativas y así desarrolló regímenes especiales como la responsabilidad que tiende hacia la responsabilidad objetiva, con prescindencia del elemento culpa, como por ejemplo: el riesgo excepcional, la responsabilidad por daño especial y los regímenes en los que no era posible probar la falla del servicio o en los que sin haber falla se producía un perjuicio que no tenía por qué soportar. 


\section{Responsabilidad en la Constitución Política}

Bajo el imperio de la Constitución de 1886, se consideraba que el Estado administrador respondía por el incumplimiento de sus contratos y por los hechos que generaran perjuicios a terceros por fuera de un contrato; no consagraba norma expresa que impusiera al Estado la obligación de reparar los perjuicios que causara por medio de sus agentes.

Cuando el Consejo de Estado asume la competencia para conocer las demandas de responsabilidad de la Administración en virtud de la Ley 167 de 1941 y empieza a separarse de las normas que regulaban la responsabilidad contenidas en el derecho privado, consolida su jurisprudencia con base en los artículos 2, 16 y 30 de la Constitución Política de 1886.Igual lo hizo en su momento la Corte Suprema de Justicia que consagraba el principio de legalidad, el deber del Estado de proteger la vida, honra y bienes de los ciudadanos y la garantía de la propiedad privada y de los demás derechos adquiridos con justo título.

Establecía el artículo 16 de la Constitución Política, reformado por el Acto Legislativo N. 1 de 1936, que: "Las autoridades de la República están instituidas para proteger a todas las personas residentes en Colombia, en su vida, honra y bienes, y para asegurar el cumplimiento de los deberes sociales del Estado y de los particulares" ${ }^{\prime \prime 3}$.

Así desarrolla el Consejo de Estado la teoría de la imputación de la responsabilidad a través de la noción de falla del servicio, que adquiere un papel relevante para justificar y delimitar la responsabilidad del Estado. Consideró el alto tribunal en sentencia de abril 18 de 1997 que:

Es primer deber del Estado procurar la realización del bien común, propósito consagrado en el artículo 16 de la Constitución; para ello dispone y organiza los Ilamados servicios públicos. Si como consecuencia de un mal funcionamiento del servicio, o de su no funcionamiento o del tardío funcionamiento del mismo se causa lesión o daño, el Estado es responsable, y por consiguiente está en la obligación de indemnizar los perjuicios ocasionados. La responsabilidad se origina en último término en el deber primario del Estado de suministrar a los asociados los medios conducentes a la efectividad de sus servicios, a la consecución de sus fines, en otras palabras, a la realización del bien común.

38 Asamblea Nacional Constituyente. CONSTITUCión POLíTICA DE COLOMBIA. Bogotá: Leyer. (1991). 
En Colombia, la consagración expresa de la responsabilidad patrimonial del Estado como norma constitucional se planteó a partir de la Constitución Política de 1991.En Sentencia C-333 de 1996, respecto a la consagración de una norma expresa de responsabilidad del Estado en el ordenamiento constitucional, la Corte Constitucional sostuvo que:

Hasta la Constitución de 1991, no existía en la Constitución ni en la ley una cláusula general expresa sobre la responsabilidad patrimonial del Estado. Sin embargo, la jurisprudencia de la Corte Suprema de Justicia y, en especial, del Consejo de Estado encontraron en diversas normas de la constitución derogada -en especial en el artículo 16- los fundamentos constitucionales de esa responsabilidad estatal y plantearon, en particular en el campo extracontractual, la existencia de diversos regímenes de responsabilidad, como la falla en el servicio, el régimen de riesgo o el de daño especial. Por el contrario, la actual Constitución reconoce expresamente la responsabilidad patrimonial del Estado, pues el artículo 90 señala con claridad que el Estado "responderá patrimonialmente por los daños antijurídicos que le sean imputables causados por la acción o la omisión de las autoridades públicas".

El artículo 90 de la Constitución Política de 1991 estableció la Cláusula General de Responsabilidad que señala que: "El Estado responderá patrimonialmente por los daños antijurídicos que le sean imputables causados por la acción u omisión de las autoridades públicas". Se constituyó así la responsabilidad del Estado como una de las piedras angulares del Estado de Derecho y como una garantía ciudadana fundamental, como lo sostuvo en su momento el constituyente y ponente de la iniciativa, el doctor Esguerra Portocarrero ${ }^{39}$.

La norma constitucional contiene una regla general de responsabilidad patrimonial del Estado con fundamento en el daño antijurídico que instituye la obligación de reparar el perjuicio, prescindiendo de todo tipo de ilicitud o culpa en la ejecución del hecho y apoyándose en la protección y garantía de los derechos de los administrados, y comprende no solo la responsabilidad, sino también el sistema de responsabilidad precontractual y la responsabilidad patrimonial del Estado de carácter contractual.

39 Id. 


\section{CONCLUSIONES}

En términos generales, a partir de la hipótesis de trabajo y la pregunta planteada, se puede afirmar que uno de los ejes centrales de cualquier ordenamiento jurídico es el régimen de responsabilidad como elemento necesario para la reparación de las consecuencias que conlleva un hecho dañoso.

El fundamento legal de la teoría de la responsabilidad en el campo civil son las obligaciones; y son fuente de obligaciones los actos y los hechos jurídicos. Es en los hechos jurídicos ilícitos en los que la responsabilidad jurídica encuentra su sustento jurídico por cuanto obliga a quien ha ocasionado un perjuicio a reparar el daño cometido.

Al ser básicamente su desarrollo jurisprudencial, la Corte Suprema de Justicia tomó para el reconocimiento de la responsabilidad del Estado los principios establecidos en la responsabilidad civil aplicando los artículos 2341 y 2349 del Código Civil, relacionados con la responsabilidad directa e indirecta.

La responsabilidad del Estado sufrió una evolución muy importante, ya que si bien al comienzo no se reconoció responsabilidad del Estado en virtud del poder soberano y absoluto del gobernante, con el surgimiento de una mayor intervención del Estado para la realización de sus fines causaba perjuicios a los ciudadanos y se le impuso la carga y el deber de ser reparados. El intervencionismo del Estado constituye así la fuente que permitió administrar la responsabilidad extracontractual del Estado.

Cuando el Consejo de Estado asume la competencia, acoge inicialmente las tesis que aplicaba la Corte Suprema de Justica para imputar responsabilidad al Estado. Sin embargo, prontamente desarrolla sus propias teorías de responsabilidad y así reafirma la noción de falla del servicio como fundamento de la responsabilidad patrimonial del Estado, cobijando con esta teoría todos los eventos en los que la Administración incurría en falta, retardo u omisión en el desarrollo de sus funciones

Hoy, la expedición de la Constitución Política de 1991 estableció la Cláusula General de Responsabilidad en virtud de la cual impone al Estado la obligación de responder patrimonialmente por los daños antijurídicos que le sean imputables, causados por la acción u omisión de las autoridades públicas. Se constituyó así la responsabilidad del Estado como una de las piedras angulares del Estado de Derecho y como una garantía ciudadana fundamental 


\section{REFERENCIAS}

Adriano De Cupis. EL DAÑo. Barcelona: Editorial Bosch. (1975).

Alier Hernández. Responsabilidad extracontractual Del Estado. Bogotá: Ediciones Nueva Jurídica. (2007).

Alier Hernández Henríquez y Catalina Franco Gómez. ReSPOnSABILIDAD EXTRACONTRACTUAL DEL ESTADO. Bogotá: Ediciones Nueva Jurídica. (2007).

Álvaro Castro Morales. Ejecución de la pena de prisión de adultos en Alemania: análisis de las leyes estaduales a la luz de la Ley Federal de 1976 y la jurisprudencia del Tribunal Constitucional Federal Alemán (BVerfG). DeRECHO PUCP 82. 2019. Págs. 281-313.

Asamblea Nacional Constituyente. Constitución Política de Colombia. Bogotá: Leyer. (1991).

Catalina Velásquez Gil. ReSPONSABILIDAD CONTRACTUAL Y EXTRACONTRACTUAL DEL ESTADO. Medellín: Librería Jurídica Sánchez. (2007).

Eduardo García de Enterría y Tomás Ramón Fernández. CURSO DeRECHO Administrativo. Tomo 1. Madrid: Editorial Civitas. (1977).

Enrique Gil Botero y Jorge Iván Rincón Córdoba. LOS PRESUPUESTOS DE LA RESPONSABILIDAD AMBientAl en Colombia. Bogotá: Editorial Universidad Externado de Colombia. (2013).

Enrique Sayague Laso. Tratado de Derecho Administrativo. Tomo 1. Montevideo: Editorial Clásicos Jurídicos Uruguayos. (2004).

Erika Mayerly Duarte Villarreal. APLICABILIDAD DE LA CARGA DINÁMICA DE LA PRUEBA EN EL RÉGIMEN DE RESPONSABILIDAD SUBJETIVA DEL ESTADO COLOMBIANO. Trabajo de grado. Universidad Católica de Colombia. (2017).

Georges Vedel. Derecho administrativo. Trad. Juan Rincón Jurado. Madrid: Editorial Aguilar. (1980).

Gustavo Penagos. EL DAÑO ANTIJURíDICO. Bogotá: Ediciones Doctrina y Ley. (1997).

Henri Mazoud y León Mazoud. Elementos de LA Responsabilidad Civil. Peruuicio, culpa y RelaCIÓN DE CAUSALIDAD. Bogotá: Editorial Leyer. (2005). 
Herbert Lionel Adolphus Harty Genaro R. Carrió. EL CONCEPTO DE DERECHO. Buenos Aires: AbeledoPerrot. (1961).

Hugo Caldera Delgado. Sistema de LA RESPOnSABILIDAd EXTRACONTRACTUAL DEL ESTADO EN LA CONSTITUCIÓn PolítICA DE 1980. Santiago: Editorial Jurídica de Chile. (1982).

Jaime Alberto Santofimio Gamboa. TRATADO DE DERECHO ADM INISTRATIVO. TOMO 2. Bogotá: Editorial Universidad Externado de Colombia. (2003).

Jaime Gamboa y Jaime Orlando Santofimio. León Duguit y su doctrina realista, objetiva y positiva del Derecho en las bases del concepto de servicio público. ReviSTA DIGITAL DE DERECHO Administrativo 5. Enero-junio 2011. Págs. 43-86.

Jairo López Morales. ReSPonSABILIDAD PATRIMONIAL DEL ESTADO. Bogotá: Ediciones Doctrina y Ley. (1999).

Javier Tamayo Jaramillo. LA RESPONSABILIDAD DEL ESTADO. Bogotá: Editorial Temis. (2000).

Javier Tamayo Jaramillo. TRATAdo De ReSPonSABILIDAD CIVIL. Tomos 1 Y 2. Bogotá: Editorial Legis. (2007).

Javier Tamayo Jaramillo. ¿Hasta dónde se puede objetivar la responsabilidad civil? Coord. Marcela Castro Cifuentes. Derecho de LAS obligaciones. Bogotá: Ediciones Uniandes. (2010). Págs. 295-314.

Jean Rivero. DereCho Administrativo. Caracas: Editorial Universidad Central de Venezuela. (2005).

Jhon M. Arredondo, José G. Obando y Milena Velandia. LA RESPONSABILIDAD SOCIAL EMPRESARIAL Y EL IMPUESTO A LA RENTA PARA LA EQUIDAD (CREE) EN EL INSTITUTO COLOMBIANO DE BIENESTAR FAMILIAR (ICBF) DE LA CIUDAD DE PEREIRA. Tesis de maestría. Universidad de Manizales. (2017).

José Félix Patiño Restrepo. Lecciones de CIRUGÍA. Bogotá: Editorial Médica Panamericana. (2000).

Juan Carlos Henao. La responsabilidad patrimonial del Estado en Colombia. Pág. 108. Disponible en http://biblio.juridicas.unam.mx/libros/3/1392/12.pdf

Lizandro Alfonso Cabrera Suárez. El control de convencionalidad y la protección de los derechos humanos en Colombia. DIXI 19. 2014. Págs. 53-70.

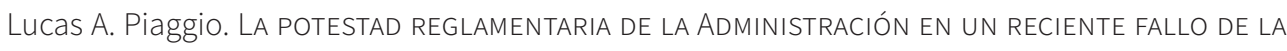
CORTE Suprema de Justicia de LA NACIÓN. Buenos Aires: Thomas Reuters. (2019). 
Marceau Long. LOS GRANDES FALLOS DE LA JURISPRUDENCIA ADMINISTRATIVA FRANCESA. Bogotá: Ediciones Librería del Profesional. (2000).

Michel Paillet. LA ReSPonsabILIdAd Administrativa. Bogotá: Editorial Externado de Colombia. (2001).

Mónica Lucía Fernández Muñoz. La culpa en el régimen de responsabilidad por el hecho ajeno. Estudios Socio-Jurídicos 1. 2003. Págs. 230-249.

Olga Cecilia González Noriega. Responsabilidad extracontractual del Estado. Una aproximación desde la teoría de la responsabilidad de los clásicos a su carácter de disciplina autónoma del derecho. ReVISTA UIS HUMANIDADES 2. 2012.

Pablo Larrañaga Monjaraz. El CONCEPTO DE RESPONSABILIDAD. México D.F.: Editorial Fontamara. (2004).

Pamela Prado López. Crítica a la configuración de la responsabilidad civil de la empresa principal y de la empresa usuaria en la Ley N 20.123. JORNADAS NACIONALES DE DERECHO CIVIL. Valparaíso, chile. 2007.

Rafael Altamira y Crevea. HISTORIA DE LA PROPIEDAD comUnAL. Madrid: J. López Camacho. (1890).

Rafael Altamira y Crevea. HISTORIA DE ESPAÑA Y DE LA CIVILIZACIÓN ESPAÑOLA. Barcelona: Editorial Herederos de Juan Gili. (1911).

Wilson Ruiz Orejuela. ResPonsABILIdAd del ESTAdo y sus Regímenes. Bogotá: Editorial Ecoe. (2010).

Wilson Ruiz Orejuela. ReSPONSABILIDAD DEL ESTADO LEGISLADOR. Bogotá: Editorial Universidad Libre. (2011). 